\title{
Cornelie Leopold|Didactics
}

University of Kaiserslautern Faculty of Architecture Department of Descriptive Geometry Pfaffenbergstrasse 95

D-67663 Kaiserslautern GERMANY cornelie.leopold@architektur.uni-kl.de Precise Experiments: Relations between Mathematics, Philosophy and Design at UIm School of Design

Presented at Nexus 2012: Relationships Between Architecture and Mathematics, Milan, 11-14 June 2012

Keywords: architectural education, design philosophy, Hochschule fuer Gestaltung Ulm, rule-based design, topology, Max Bill, Max Bense, Abraham Moles,

Abstract. The strong relationship between theoretical background in structural thinking and practical realization in composing and designing was one of the characteristics at Hochschule fuer Gestaltung (HfG) Ulm, the Ulm School of Design. This paper examines the special relationship between mathematics, philosophy and design at HfG Ulm, illustrated by examples of the foundation courses. This design approach assumes new relevance today in reference to rule-based or parametric designing with digital tools.

\section{Introduction}

There is a long tradition of using structures that are geometric, and in general mathematical, as a foundation for design disciplines. The understanding of mathematics as a general structural science, developed in the 1930s, was picked up in the 1960s in the cybernetic structuralist approach in designing. Structural thinking in reference to mathematical and cybernetic structures was one of the most important aspects of teaching at the Hochschule fuer Gestaltung" (HfG) Ulm, the Ulm School of Design. Practical realizations in composing and designing based on theoretical foundations are characteristic of this experimental school. HfG Ulm existed for only a short time (19531968) but had a tremendous influence on the further development of design disciplines, first through the theoretical background it introduced, and then through the impact of its teachers and students, who later became professors at universities all over the world. The school gained a high international recognition. There have been several publications about Ulm School of Design, but these have mainly concentrated on the school's history and the conflicts between the teachers. It is time to look in greater detail at the contents at HfG Ulm. This is not an easy task, because there were so many people with various influences. The few years of this experimental school look like a melting pot of the intellectual analysis of the requirements for the new technical and industrial period combined with innovative and creative approaches that led to new generations of design, especially in the field of industrial, product and graphic design.

Here I will try to analyse the relationship between mathematics and design at HfG Ulm, the connection between structural thinking and composing as it was realized, for example, by the interaction at the HfG Ulm between the philosopher and science theorist Max Bense and the architect and artist Max Bill. The foundation courses offered there will be analysed with regard to their mathematical and geometric contents. Numerous exercises there were based on the mathematical investigations. Tomás Maldonado, who taught at HfG Ulm between 1954 and 1966, and was later a professor at the Politecnico di Milano, refined the foundation course with a focus on methodology, where sciences were seen as foundation for design. 
Today the design approaches at Ulm School of Design become newly relevant in reference to rule-based or parametric designing with digital tools. A missing theoretical background for current trends may be found in these early experiments, which sometimes represent the very first experiments and ideas regarding new methods and their scientific background. It is therefore worth going deeper into the analyses of the background at Ulm School of Design, which we will start here.

\section{Short history of Ulm School of Design}

The HfG Ulm was founded in 1953 with Max Bill as the first rector. The School grew out of the adult education school in Ulm, founded by Inge Scholl, sister of Hans and Sophie Scholl, who were executed by the Nazis in 1943 for distributing anti-Nazi flyers, and the graphic designer Otl Aicher. The idea arose out of the necessity of creating a centre of active contemporary culture and democratic education of German society after World War II. The founders saw political education and environmental design as fundamental for developing a democratic society. The Geschwister-Scholl-Stiftung (Scholl Siblings Foundation) became the supporting institution of the Ulm School of Design. The project was supported financially by John McCloy, US High Commissioner for Germany, the Norwegian European Aid Program, and the West German Finance Directorate. At first the concept of the school focused more on politics and journalism, but with the involvement of Max Bill it shifted to design, which was a helpful direction with regard to reconstruction and economic growth in post-war West Germany:

The turn towards design put the Ulm School in line with the policy of consolidation of the young democracy through prosperity and integration into the West, driven by the United States in response to the East-West conflict [Ulmer

Museum/HfG-Archiv 2003: 16f].

At the beginning the Ulm School of Design was guided by the Bauhaus principles but soon the design of industrially produced objects and buildings as well as the design of products of mass communication become the main fields. As Max Bill stated in an interview: "...we understood the needs of this task as if the Bauhaus had developed further during the whole Nazi period” [Krampen and Hörmann 2003: 39].

New approaches in design were investigated and put into practice within the departments of Visual Communication, Industrial Design, Building, Information and, later, Film. There were students from all over the world: over the course of the school's history there were 639 students from 39 countries, 21 professors and 216 guest lecturers [HfG-Archiv/Ulmer Museum 2007].

The development of the concept of design pedagogy at Ulm School of Design can be described in three phases:

1. Foundation Phase with Bauhaus foundation course (1953 - 1958);

2. Scientification of the design process $(1958-1962)$;

3. Design practice influenced by the social sciences $(1962-1968)$.

In these different phases the foundation course underwent various changes according the positioning of the design approaches. 


\section{Mathematics in the foundation courses}

During the years, many teachers and guest professors were involved in the courses at Ulm School of Design. Therefore it is a long task to describe all the different inputs. We want to concentrate our analysis on a few of the most interesting points regarding the relationship of mathematics to philosophy and design.

In the first years from 1953 to 1958 the HfG referred in its foundation course to the experiences of the Bauhaus. It concentrated on a visual training of eye and hand, freehand drawing and experiments with materials. Max Bill, the first rector of HfG, himself a former student at the Bauhaus, engaged Helene Nonné-Schmidt, Walter Peterhans, Josef Albers and Johannes Itten as guest teachers for the first course, which started in August 1953. The foundation course was a one-year course. In the first and second phases the course was the same for all students.

\section{The course of Josef Albers}

To look more in detail we take the foundation course taught by Josef Albers in 1953/54, which is recorded in a film script written by Albers in 1954 [Krampen 2009]. Martin Krampen, a former student and later a lecturer in Ulm, wrote in the booklet:

The first two parts of the foundation course, which initiated the education program at the newly founded Ulm School of Design in fall of 1953, had little to do with the 'Vorkurs' at the Bauhaus. The first part, taught by the Bauhaus photography teacher Walter Peterhans, was developed at the Illinois Institute of Technology in Chicago at the suggestion of Mies van der Rohe to provide architects with an introduction to visual communication. The second part was taught by Josef Albers; he had developed it beyond the level of his Bauhaus course at the North Carolina Black Mountain College after his emigration to the U.S. in 1933 [Krampen 2009: 7].

Albers developed this concept later on in his teaching at Yale University's design department in 1950. Albers wrote in the film script:

During my guest lectures at the Ulm School of Design, students there made this film in order to publish in images my teaching principles and methods, first developed at the Bauhaus and then further extended in the USA. I teach learning to see. Everything that can be taught in art is observation and formulation. We 'see' not only with the visual sense, but also with the tactile sense and with the motor sense.

Albers approach was an artistic one, but based on geometric principles. The sequence of the course topics was "Drawing", "Study of Material" and "Color". We want to have a look at the course under the aspect of geometric content in his approach. In the part "drawing" the geometrical transformations were important elements. In a basic exercise the students drew a line in any plane figure, which was then used as a axis of reflection (fig. 1).

In all his exercises the motor sense was very important, so students worked often by freehand sketching. The symmetrical studies were followed by similarity and proportion studies. There were series of exercises about similarity, starting with a triangle and drawing parallels creating similar triangles (fig. 2). 
Other drawing examples deal with proportional transformations of rectangles with the help of a diagonal and changing proportions ending in a line (fig. 3).
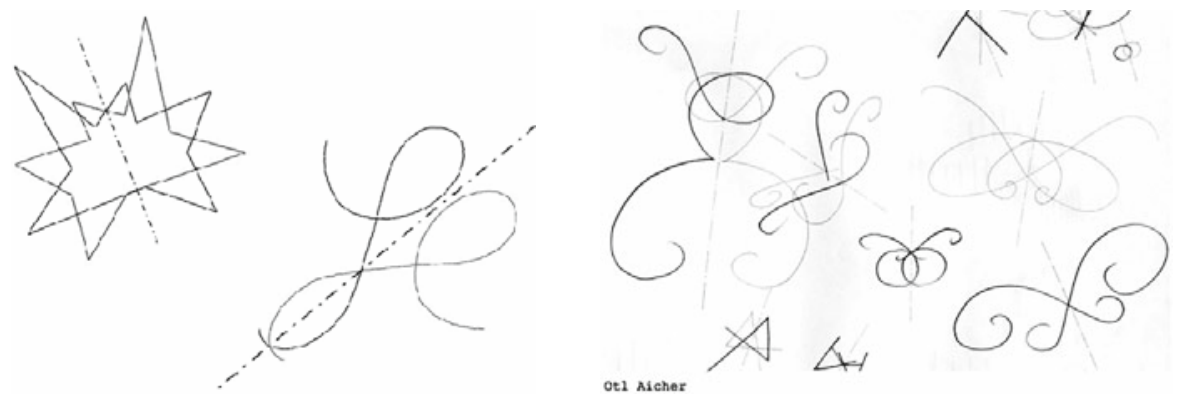

Fig. 1. Symmetrical doubled figures in Albers' course (left) and sheet by Otl Aicher (right) [Krampen 2009]. Reproduced by courteous permission of Martin Krampen

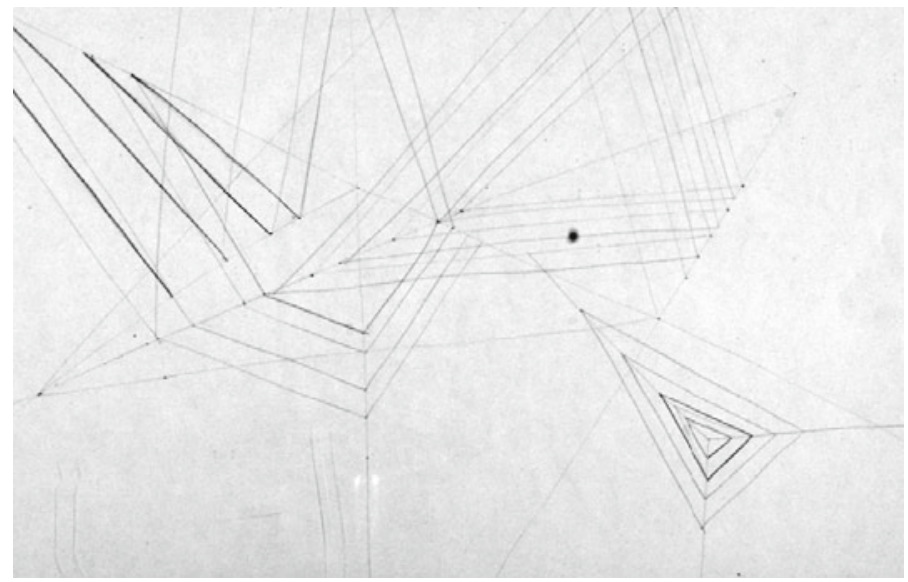

Fig. 2. Repeated forms by parallels-similar triangles. Drawing by Immo Krumrey [Krampen 2009]. Reproduced by courteous permission of Martin Krampen
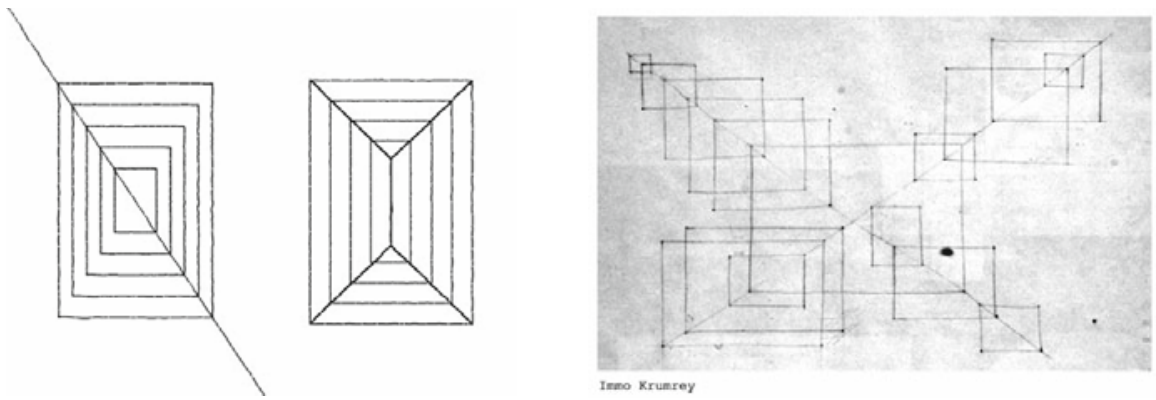

Fig. 3. Repeated forms - proportional and mitered rectangles (right) and sheet by Immo Krumrey (right) [Krampen 2009]. Reproduced by courteous permission of Martin Krampen

These were some basic examples of a geometric concept of drawing in the foundation course. But even the module "Study of Materials" had a geometric approach by categorizing the materials as linear and flat materials. Then Albers showed examples of how to build spatial objects by linear and planar patterns (fig. 4). 

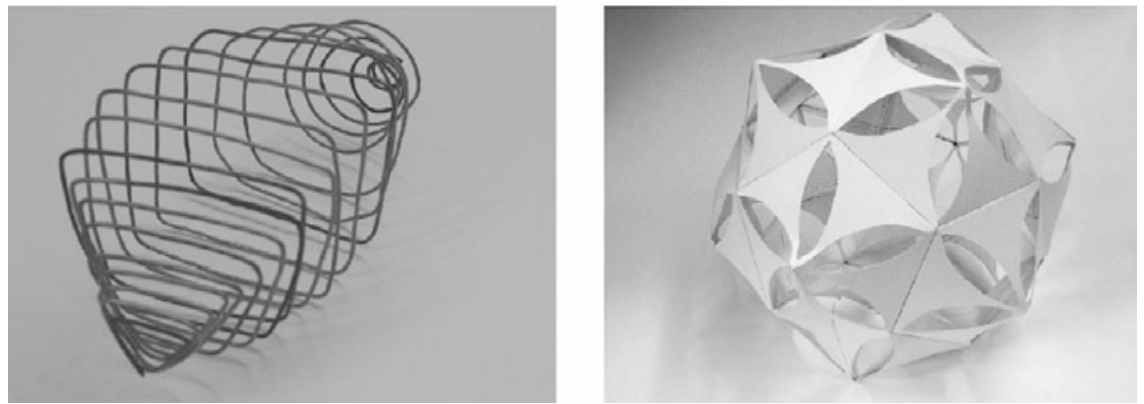

Fig. 4. Linear and planar building materials [Krampen 2009].

Reproduced by courteous permission of Martin Krampen

In the module "Paper Folding" we find experiments in creating three-dimensional spatial configurations out of two-dimensional materials. This is also a geometric approach although one that is experimental, not theoretical. The experiments look like those carried out today (fig. 5).
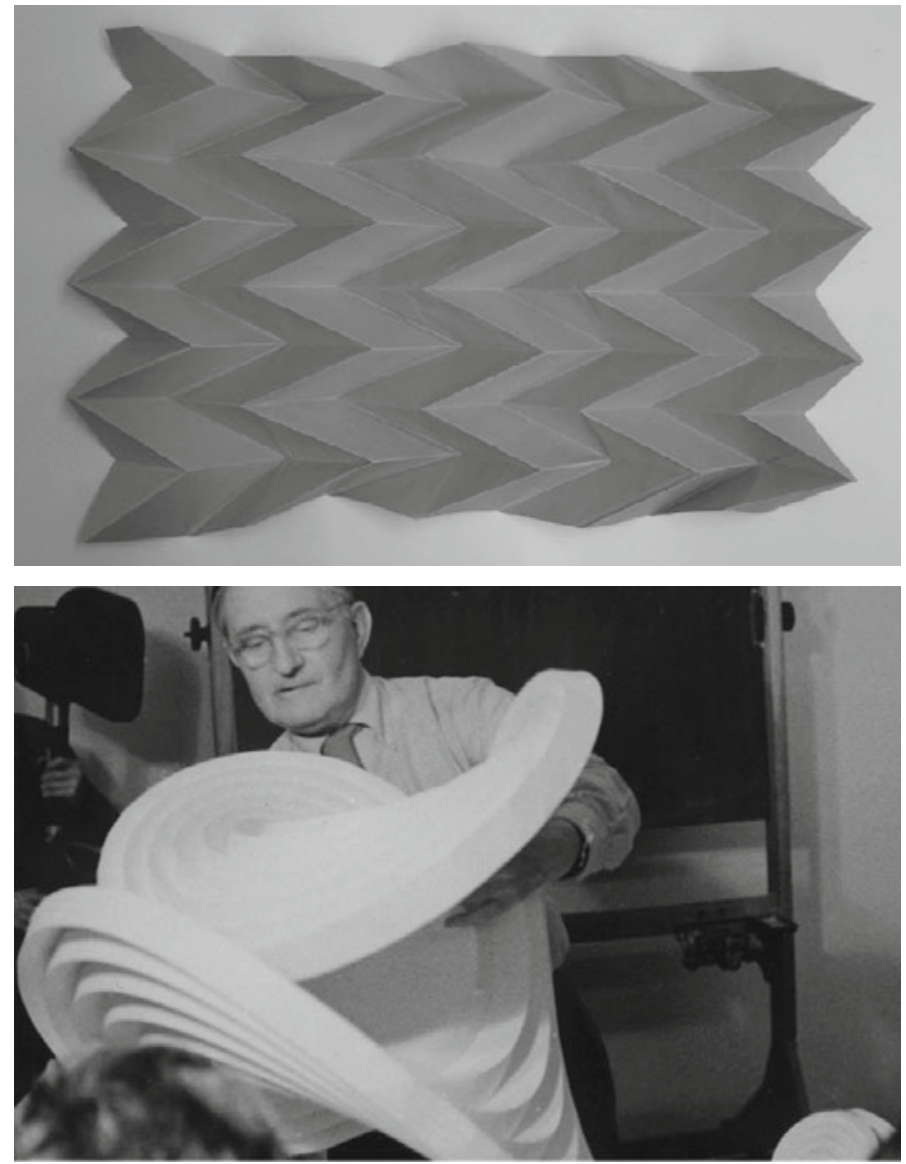

Fig. 5. Zigzag folding (above) and curved folding object (below) by Josef Albers.

(C) The Josef and Anni Albers Foundation / VG Bild-Kunst, Bonn 2013 

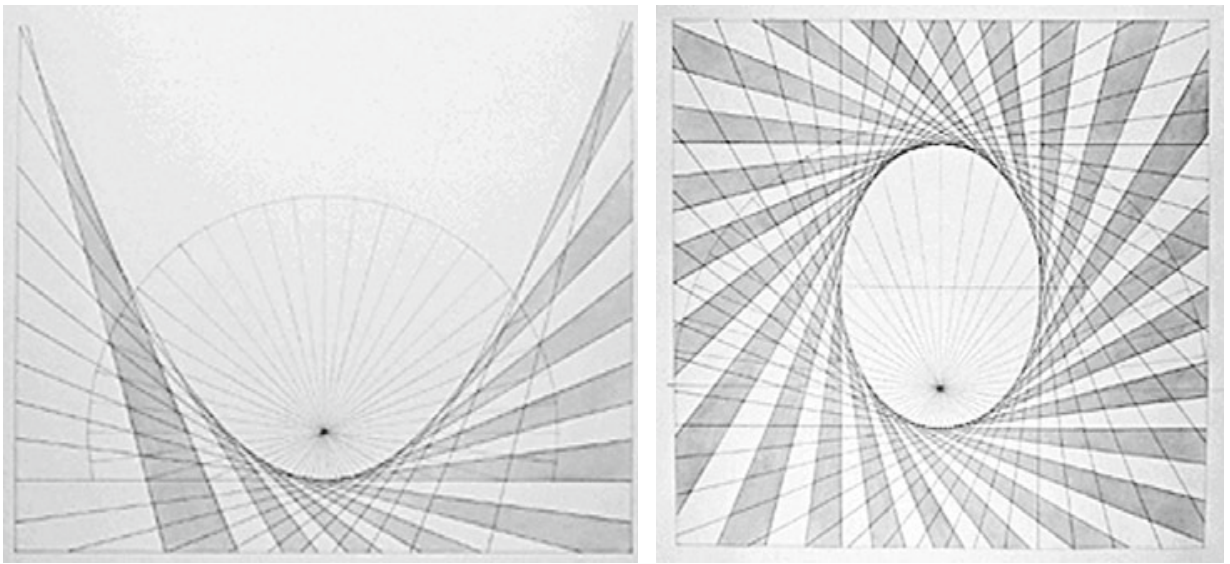

Fig. 6a-b. Exercises from the class taught by Hermann von Baravalle. Creating parabola and ellipse by moving a right angle by student Dominique Gilliard, 1955/56. Photo: Oleg Kuchar.

(C) HfG-Archiv, Ulmer Museum Ulm

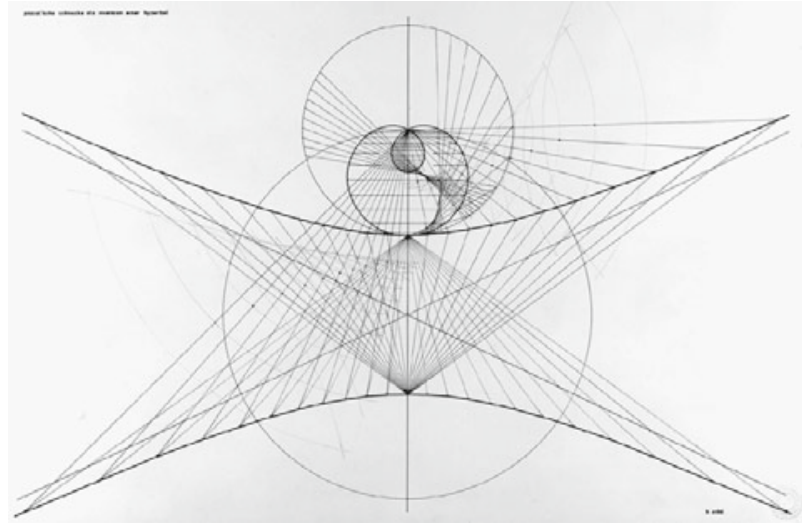

Fig. 6c. Limacon of Pascal as inversion of a hyperbola in course constructive geometry by student Hermann Edel 1956. Reproduced by courteous permission of Hermann Edel

The course of Albers was taught twice at Ulm School of Design, 1953/54 and 1955. Max Bill did not teach directly in the foundation course but made his ideas felt by selecting the teachers and accompanying some tasks with his critiques. In this first foundation course we see references to the earlier Bauhaus course, but the new step was that Bill and Albers reduced the foundation course to a design that was not oriented toward any particular object.

Besides the approach from art, Hermann von Baravalle taught the subject "constructive geometry" from 1955 to 1959, integrated in the foundation course. He came from the tradition of Waldorf education and represented a dynamic understanding of geometry. The studies of geometric principles, developed from movements of points and lines, are typical of his approach (fig. 6a-c).

These examples show the dynamic interpretation of geometry by Baravalle, which he described also in his 1957 book Geometrie als Sprache der Formen (Geometry as language of forms) [1963]. The tangents envelope the conic section curves. This concept 
includes the general common definition for parabola, ellipse and hyperbola as the geometric locus of points whose distances between a point, called a focus, and a line, called a directrix (straight line or circle), are the same. The inversion of curves is another dynamic example from the constructive geometry course. This dynamic geometry approach fit well in the practical and action-oriented way of Albers.

\section{New course concept by Tomás Maldonado}

A new type of foundation course that contained a more scientific approach was conceived by Tomás Maldonado. It remained non-object-oriented and preserved the way of Albers, but the main focus involved working and designing on the basis of theoretical knowledge in perception theory and mathematics. The subject "Visual Methodology" was the main field of the foundation course in this second phase. The aim was to train the students in the conscious and controlled handling of design processes. The new foundation course, later called "Ulmer Modell" included the following scientific disciplines: Perception and Gestalt Theory; Symmetry Concepts; and Topology.

William S. Huff, student from the U.S. and later teacher at HfG Ulm, described in an interview the concept of Maldonado's foundation course:

Maldonado came to Ulm in the second year. ... So he started thinking about better ways of doing the 'Grundlehre'. In the third year, 1955/1956, he took on teaching the 'Grundlehre'. He carried on what might call the purification and renovation of the Bauhaus direction. He preserved what Albers had done at the Bauhaus. But at the same time he introduced something more: He made it interdisciplinary. He brought in some other subjects, such as symmetry and topology and a good dose of Gestalt theory. He introduced information about these subjects into the course, which Albers had not done. ... But Maldonado was a person who wanted you to know where the different parts of these disciplines came from [Krampen and Hörmann 2003: 101-103].

The most important aim was to mediate a way of thinking that could be later used for the applied design tasks. The tasks assigned by Maldonado did not have a reference to practical design. The focus was on a methodical approach. Whereas Albers' and Bill's art approach was directly linked to mathematical thinking, Maldonado started with theory and mathematical concepts. An example of Maldonado's foundation course in 1957/58 still shows a strong relationship to Bill's approach. The solution devised by a student in Maldonado's course to the task of dividing a sphere in two equal parts shows another variant of the solutions in Bill's family of five half-spheres, which he created for the Institute of Mathematics at University of Karlsruhe in 1966. For several years Bill experimented with the dividing of solids such as cubes, spheres and tori (fig. 7a-b).

The main difference, which started as a new model in this phase, was the role of art and aesthetics. Whereas Bill insisted on the overall important role of art for designing related to mathematics, Maldonado said in 1958:

The aesthetic factor merely constitutes one factor among others with which the designer can operate, but it is neither the principal nor the predominant one. The productive, constructive, economic factors - perhaps, too the symbolic factors also exist. Industrial design is not an art nor is the designer necessarily an artist [Ulmer Museum/HfG-Archiv 2003: 40]. 

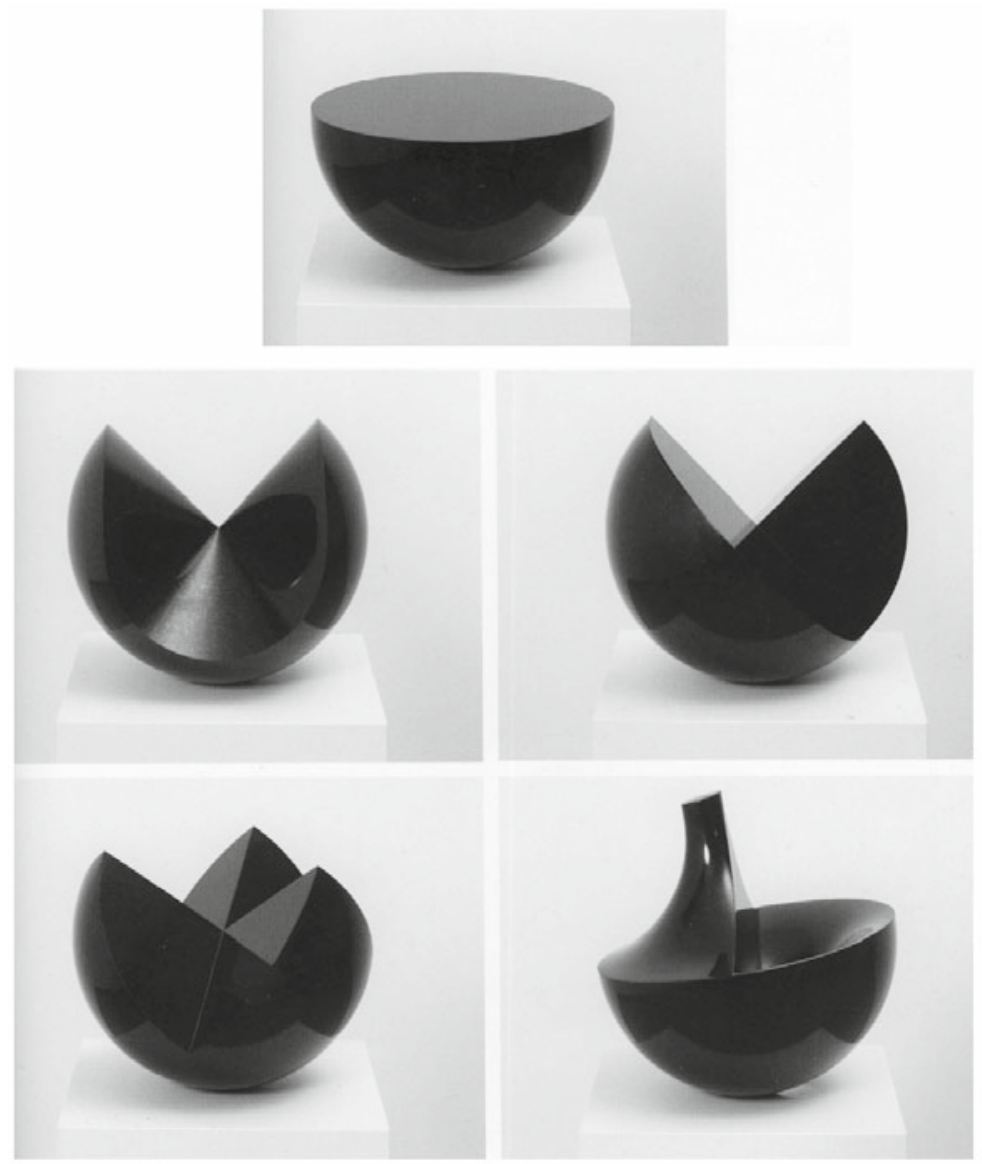

Fig. 7a. Family of five half-spheres by Max Bill 1965/66 [Buchsteiner and Letze: 2005: 145]. (C) VG Bild-Kunst, Bonn 2013

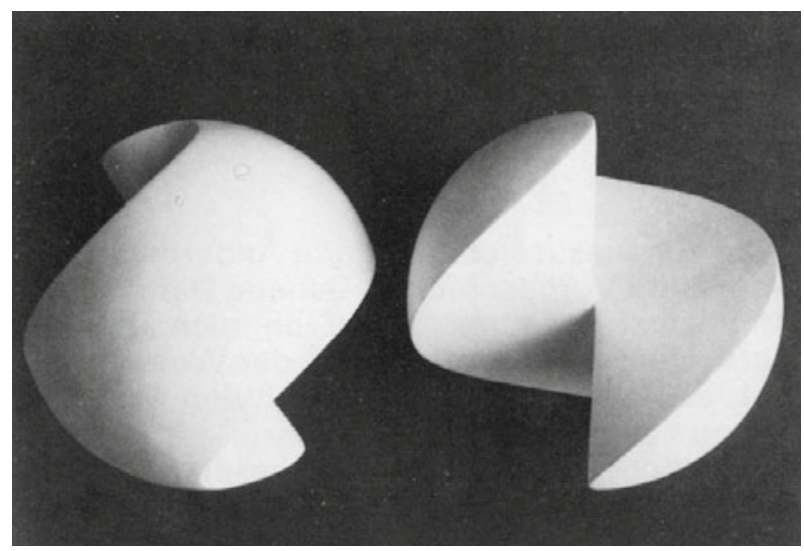

Fig. 7b. Exercise in dividing the sphere into equal halves by student Eduardo Vargas 1957/58, produced during the course of Tomás Maldonado. Photo: Christian Staub [Lindinger 1987: 51]. (CHfG-Archiv, Ulmer Museum Ulm 
A list of the assignments of Maldonado's foundation course "Visual Introduction" in 1955/56 included Sierpinski triangles, Peano curves, Weierstrass curves, black as color, symmetries, exact through inexact, inexact through exact, spatial effect, balancing of three planes and interruption.

The following year, 1956/57, new material were added in the course, especially regarding exercises in tiling and perception. William S. Huff, student in the foundation course in 1956/57, described the foundation courses in an essay [Ulmer Museum/HfGArchiv 2003: 173ff.].

Maldonado invented "katametry" in the course based on the ideas of the German chemist K.L. Wolf. In a task of Maldonado, katametry is defined as rotation-dilation around a centre [Lindinger 1987: 57] (fig. 8). With this concept different levels of structures can be distinguished, and we become aware of the background of a theory of symmetrical structures. Huff later worked on these ideas in the U.S., which he explained in an essay entitled "Ordering Disorder after K. L. Wolf” [2000], where he compared the system of Wolf (fig. 9a) with the typology of mapping after March and Steadman (fig. $9 \mathrm{~b})$. "Katametry" (literally, low measure) is seen as the lowest level of symmetric structure.

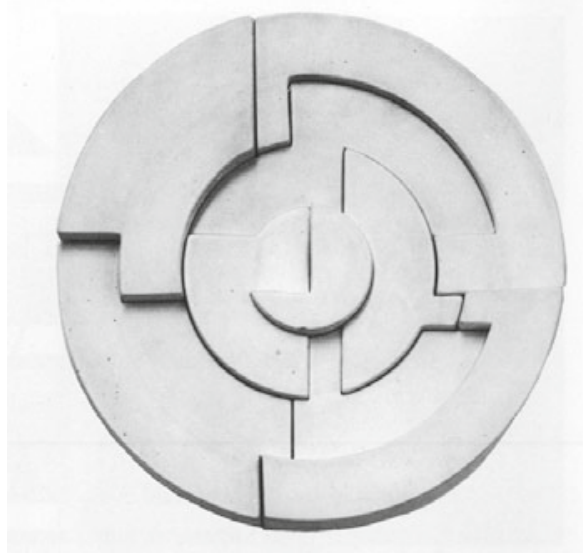

Fig. 8. Form-fitting net of katametric elements by student Klaus Schmitt in the course of Tomás Maldonado [Krampen and Hörmann 2003: 101f.] (C) HfG-Archiv, Ulmer Musuem Ulm

Additionally, topology became an important field for Maldonado, allowing him to look at structure in a completely different way. Maldonado and Gui Bonsiepe reflected on the role of topology in their essay "Wissenschaft und Gestaltung" [1964]. The designer could be prepared by topology to approach a problem in another way; problems involve not only dimensions, forms and positions, but also order, continuity and neighbourhood. However, they realised that the application of topology in the practice of product design was not satisfying [1964: 14]. The examples of non-orientable surfaces remained exercises (fig. 10).

Huff concludes:

Thus, the basic design component of the 'Grundlehre' under Maldonado, though expanded interdisciplinarily in respect to Albers' version of it, remained wholly abstract, wholly nonobjective - dealing purely and solely with formal, syntactic, issues [Ulmer Museum/HfG-Archiv 2003: 182]. 


\begin{tabular}{|l|c|c|c|c|c|c|}
\hline & position & size & angle & shape & certainty & rule \\
\hline autometry & $\mathrm{I}$ & $\mathrm{I}$ & $\mathrm{I}$ & $\mathrm{I}$ & $\mathrm{I}$ & $\mathrm{I}$ \\
\hline isometry & $\mathrm{V}$ & $\mathrm{I}$ & $\mathrm{I}$ & $\mathrm{I}$ & $\mathrm{I}$ & $\mathrm{I}$ \\
\hline homoeometry & & $\mathrm{V}$ & $\mathrm{I}$ & $\mathrm{I}$ & $\mathrm{I}$ & $\mathrm{I}$ \\
\hline syngenometry & & & $\mathrm{V}$ & $\mathrm{I}$ & $\mathrm{I}$ & $\mathrm{I}$ \\
\hline katametry & & & & $\mathrm{V}$ & $\mathrm{I}$ & $\mathrm{I}$ \\
\hline hypometry & & & & & $\mathrm{V}$ & $\mathrm{I}$ \\
\hline heterometry & & & & & & $\mathrm{V}$ \\
\hline ametry & & & & & & \\
\hline
\end{tabular}

Fig. 9a. Levels of structures after Wolf and Wolff [1956]. I = Invariant; V = Variant, after [Huff 2000: 43]

\begin{tabular}{|c|c|c|c|c|c|c|c|}
\hline mapping & 蒙 & position & length & $\begin{array}{l}\text { angle } \\
\text { and } \\
\text { ratio }\end{array}$ & parallelism & $\begin{array}{c}\text { cross- } \\
\text { ratio }\end{array}$ & neighborliness \\
\hline identity & & $\bullet$ & $\bullet$ & $\bullet$ & $\bullet$ & $\bullet$ & $\bullet$ \\
\hline isometry & & & $\bullet$ & $\bullet$ & $\bullet$ & $\bullet$ & $\bullet$ \\
\hline similarity & & & & $\bullet$ & $\bullet$ & - & - \\
\hline affinity & & & & & $\bullet$ & $\bullet$ & $\bullet$ \\
\hline perspectivity & & & & & & $\bullet$ & $\bullet$ \\
\hline typology & & & & & & & - \\
\hline
\end{tabular}

Fig. 9b. Typologies of mapping after March and Steadman, after [Huff 2000: 43]
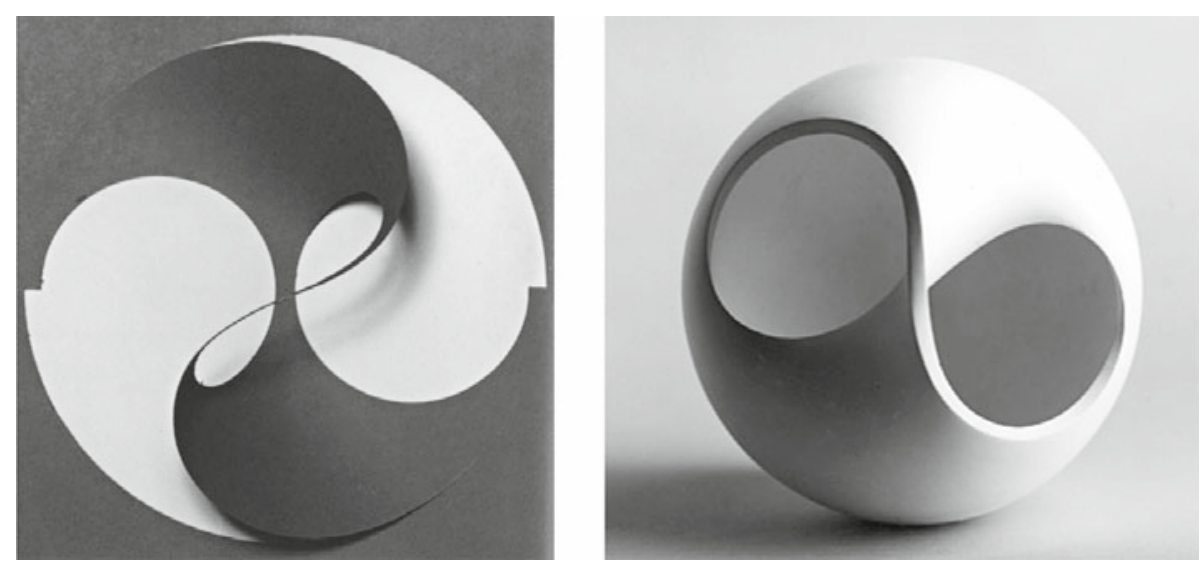

Fig. 10. Non-orientable surface made of paper and plaster by student Ulrich Burandt 1956/57, in the course of Tomás Maldonado. Photo: Christian Staub

[Ulmer Museum/HfG-Archiv, 2003: 64f.] (C HfG-Archiv, Ulmer Museum Ulm

Already implicit in this quote is the criticism, which arose after the first years, that there is too large a gap between foundation course and design practice. But there had been differences between the teachers already in the first years. 
Some instructors, for example the architect Herbert Ohl and sculptor (later product designer) Walter Zeischegg, used examples in the foundations course that could be applied for practical design. Walter Zeischegg was the only teacher besides Otl Aicher who taught and worked at the school from its founding to its closing. He was involved in the general foundation course in various subjects, such as technical drawing and design. He stated that he wanted to achieve three things in teaching the future designers: 1) provoking the imagination; 2) training the ability to represent; 3) sublimating the ability to perceive and differentiate. Although this sounds very general, the students' projects show already relations to applied designs, but the approach was nevertheless strongly geometric. In opposition to the motto "form follows function", Zeischegg saw the function only as a basic condition for the form development. With his morphological studies he arrived at the conclusion first there has to be the form before function, because function is seen as the dependency on another form. For him, functionality was subordinated form. The examples shown in fig. 11 from the foundation course in $1959 / 60$ give an idea of his way of teaching, working with geometric tasks but developing the application for design products.
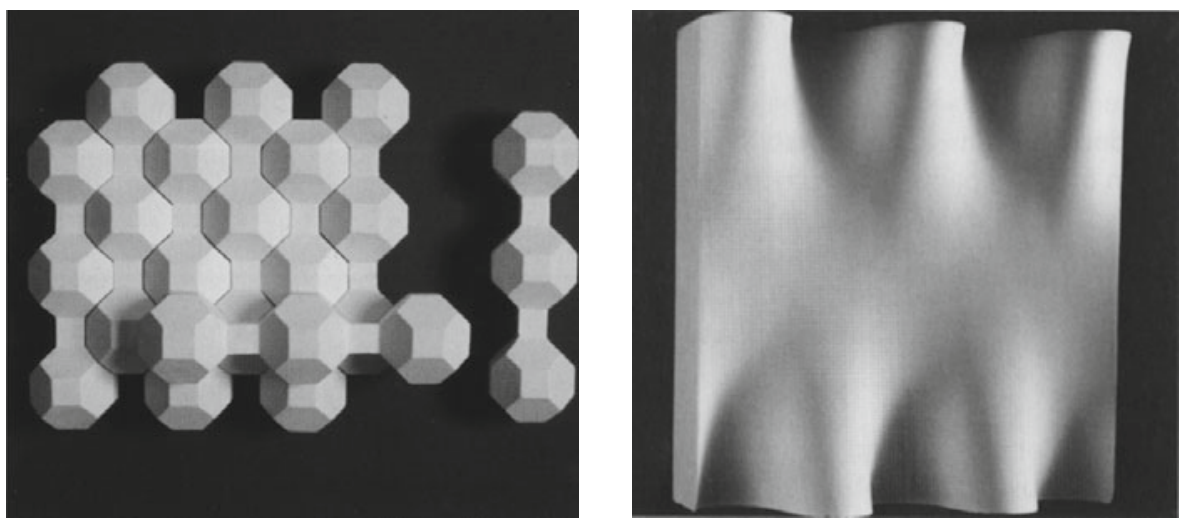

Fig. 11. Exercises from the course in product design of Walter Zeischegg 1959/60.

Left) Use of space without gap, positive-locking stacking solids by student Herbert Falk; right) transitional surface by student Rudi Dahlmann, [Krampen and Hörmann 2003: 120]. Photos both images: Christian Staub (C) HfG-Archiv, Ulmer Museum, Ulm

Another example of a mathematical approach with a direct application in design, in this case architecture, is an example by Anthony Froshaug, who came from London and taught at HfG Ulm from 1957 until 1960 in the Visual Communication department. In 1959 he taught "visual methodology" in the foundation course. He said that his aim in the foundation course was to foster a systematic way of working. The students had to work on patterns and grids systematically, first in two dimensions and then in three (fig. 12). A general ideas of graphs was developed out of the understanding of grids. Froshaug gave an example of a floor plan of Le Corbusier for a house in La Plata in 1954 (fig. 13).

He explained the role of graphs for the visualization of circulations. After finishing the building Le Corbusier had to remodel the house because the arrangement of the rooms was inappropriate. Froshaug suggested writing down the possible ways of circulation in a matrix, after numbering the rooms. The maximal row sum is 5 . Therefore, a grid where at least five lines meet in each point is necessary. From among all the grids shown in fig. 12, type 3.6 was selected as appropriate. Thus he arrived the graph in shown in fig. 14. 
The example gives an impression of the more abstract systematic mathematical approach in this phase, whereas at the same time there is a direct application to architectural practice.
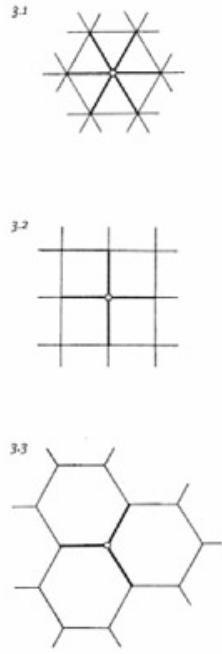

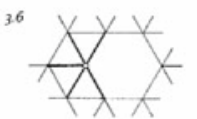

3.4

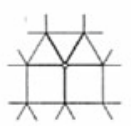

3.8

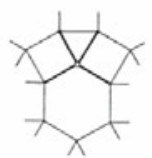

3.5

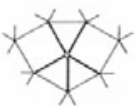

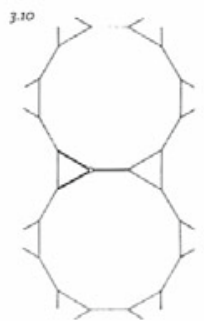

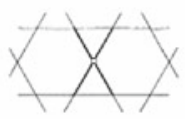

3.9

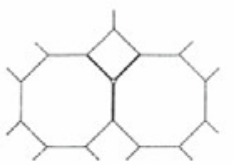

3.11

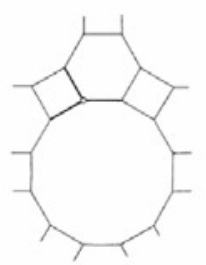

Fig. 12. Patterns and grids [Froshaug 1959: 2-3].

Reproduced by courteous permission of Gui Bonsiepe, Ulmer texte (http://ulmertexte.kisd.de)
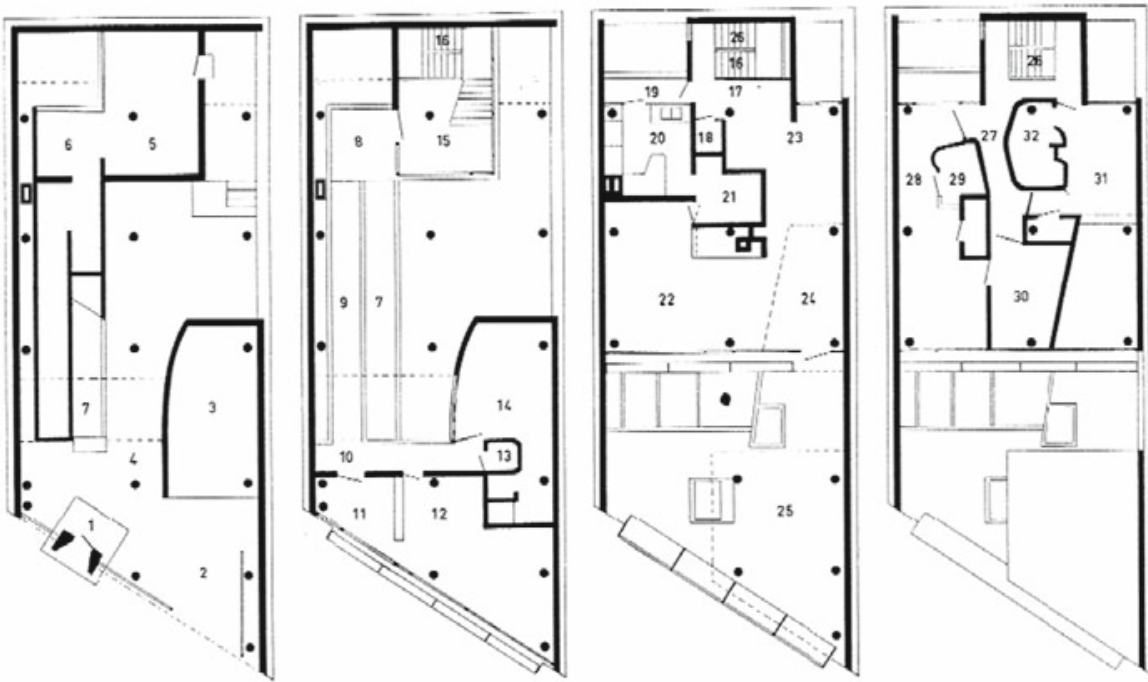

Fig. 13. Floor plans of the house Casa Curutchet in La Plata, designed and built by Le Corbusier in 1954 [Froshaug 1959: 7]. @ FLC/ VG Bild-Kunst, Bonn 2013 

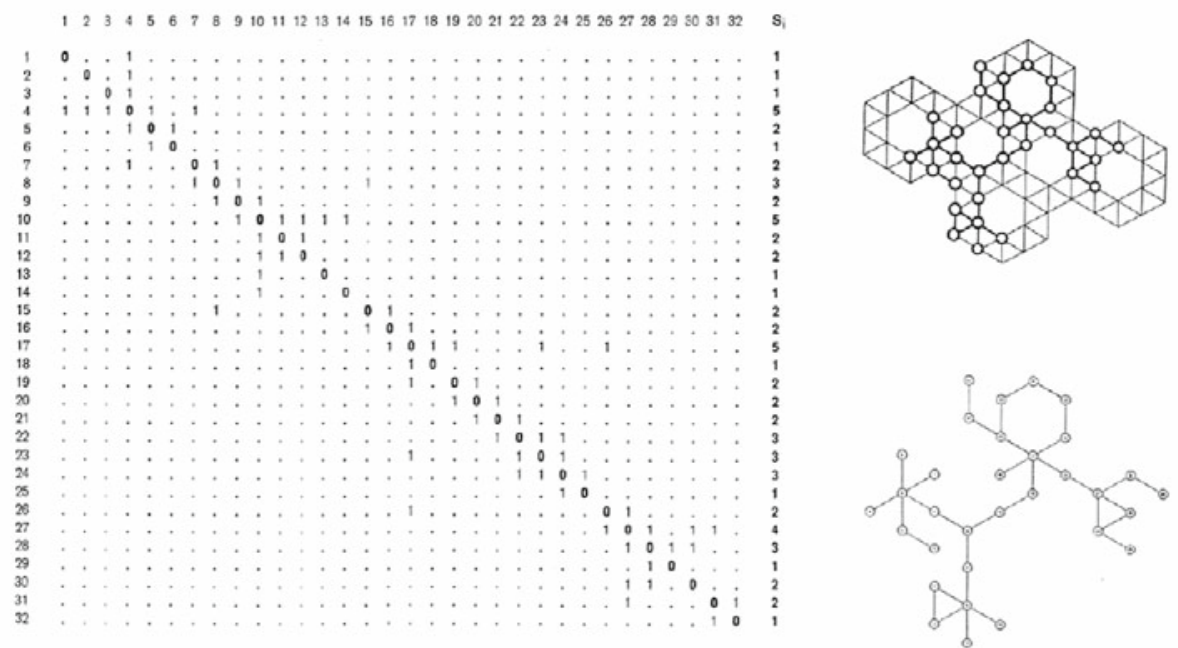

Fig. 14. Matrix and graphs of the circulation ways [Froshaug 1959: 7-8]. Reproduced by courteous permission of Gui Bonsiepe, Ulmer texte (http://ulmertexte.kisd.de)

\section{Foundation courses in individual departments}

In phase 3 of Ulm School of Design (1962-1968) each department had its own foundation course. Maldonado stated that an overall foundation course was not the best solution. He introduced the new concept with a diagram (fig. 15). The diagonal line divides the rectangles in Basic and Applied Design. Special introductory courses for architecture, product design, and visual communication were introduced.

\begin{tabular}{|c|cc|}
\hline 1 & 3 & 4 \\
\hline Design-non-applied & & \\
\hline & & \\
\hline & Design-applied \\
\hline
\end{tabular}

Fig. 15. Non-applied and applied design in the curricular model by Maldonado [Ulmer Museum/HfG-Archiv, 2003, p.193]. (C) HfG-Archiv, Ulmer Museum, Ulm

Here too the courses started with non-object orientated tasks, but these became increasingly linked with applications in their respective fields.

The studies regarding form fitting and stacking solids were especially important in the departments of product design and architecture. There had been intensive studies on polyhedral geometry and packaging by various teachers together with Helmut Emde, who taught constructive geometry from 1961 to 1968. This research field had an impact on the designing of structural systems and modular building systems.

There are many other people whose mathematical impact on designing at Ulm School of Design was important. For example, Horst Rittel, with the subject methodology and mathematical operations analysis, influenced new methodological approaches to a large extent. The analysis of his impact at Ulm School of Design merits treatment in a separate paper. The philosopher Elisabeth Walther taught methodology and logic. The artist Kurd Alsleben worked on structure theory and Boolean algebra. An 
in-depth examination has to be left for a future research, as here I have focused on the more geometric aspects of mathematics in the foundation courses.
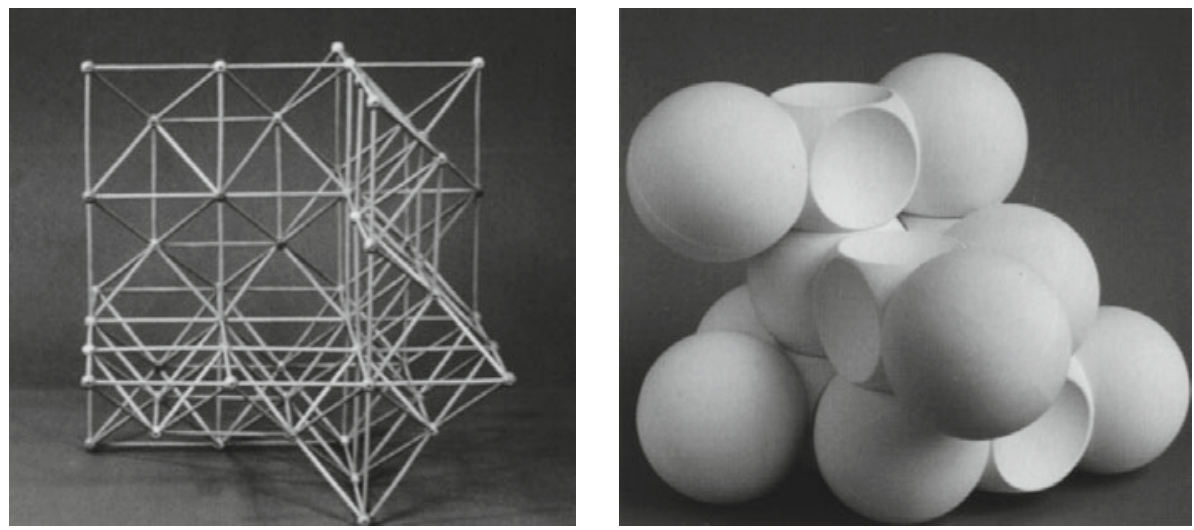

Fig. 16. Left) Exercise with lattice structure as hollow solid by student Jörg Stumpp; teacher: Günter Schmitz 1963/64; Right) Exercise of isometric unit of elements by student Georg Hilsmann; teacher: Gui Bonsiepe. Photo: Roland Fürst [Krampen and Hörmann 2003: 263]. Both images () HfG-Archiv, Ulmer Museum, Ulm

\section{Relations between mathematics, philosophy and design at HfG UIm}

The 1951 mission statement of the Ulm School of Design explained:

School of Design: Its range of activity consists of those areas of design which largely determine the way of life of our technical and industrial age. The form of instruments we use, our dwellings, the plan of a housing development, city, or region, the printed and spoken word in press and radio, the effect of images in publications, advertising, exhibitions, and film constitute crucial foundations for the mentality of our society [Ulmer Museum/HfG-Archiv, 2003, p.12].

Here design was brought into relation to the technical, industrial and information age as the crucial foundation for the new school. In 1952 the German philosopher Max Bense, a professor for philosophy and theory of science at the Technical University Stuttgart since 1949, was invited by Inge Scholl to give a public lecture entitled "Technology, Tradition, and Revolution" at the Volkshochschule. He was then engaged to teach at Ulm School of Design. Bense had worked on the implications of the relationship between technology and society. In his essay "Technische Existenz", he described the human-world relationship as a technical one. His belief that designed objects have to be seen as part of larger mathematical structures is expressed there as follows:

We do not occupy landscapes and gardens, no houses at a smooth hillside or on a light groundswell, we occupy a net of visible and invisible functions and relations, structures and aggregates of metals and artificial rocks, which they have called villages, cities, countries and continents [Bense 1998: 121].

In reference to the technological world, rationality and clear methodological thinking should be the pre-conditions.

In many of his writings Bense also analysed the relations between art and mathematics. In his book Konturen einer Geistesgeschichte der Mathematik II - Die 
Mathematik in der Kunst [1949] he wrote that his research on the history of ideas in mathematics and art led him to the conclusion that every appearance of a new style in the European art was linked to the introduction of mathematical methods and theorems on which the formal elements of that style could be traced back more or less consistently and completely [Bense 1949: 207].

Bense's philosophical considerations of technology, mathematics, and aesthetics made him a perfect fit for the aims of the Ulm School of Design. He taught philosophy, aesthetics and semiotics at HfG from 1953 to 1958 and again in 1965-66. His former students expressed the importance of his teaching not only for the theoretical foundations, but also for the design practice. For example, Gui Bonsiepe wrote in an interview:

Bense had the great and fascinating capacity to captivate the students through his lectures. He was fresh. He formulated very well. He had the gift of aesthetic differentiation. ... To Bense I owe the examination of mathematics and the mathematical foundations of information theory [Krampen and Hörmann 2003: $155]$.

His collaborations with Bill were especially fruitful. Their interaction has an impact of the relationship of the philosophical foundation to practical designing. Former student Almir Mavignier, later Professor of Art in Hamburg, described Bense's influence on his practical work: "He was my most important teacher ... He formed us solely through his theory" [Krampen and Hörmann 2003: 201-203]. He then went on to explain that working in his art with deformation was the idea of Bense in opposition to a work of Bill with a highest amount of information. This example shows that the theoretical inputs in the field of information theory, aesthetics, and semiotics, which had been in close relationship to mathematical methods, had an especially large influence on design practice.

Mathematics played an important role in the work of Max Bill. In his article "Die mathematische Denkweise in der Kunst unserer Zeit" (Mathematical Ways of Giving Form in the Art of our Time) [1949] Max Bill had described the importance of mathematics for art. An important step for him was the 1912 book by Kandinsky, Über das Geistige in der Kunst, where Kandinsky explained a way coming to the consequence that substitutes mathematical thinking in place of fantasy, without having taken this step himself. Bill explained that it is possible to develop an art based on a mathematical way of thinking.

The combination of the designers, researchers, and teachers in the fields of theory and practice was the most characteristic feature of the Ulm School of Design. This could be only achieved through personalities with affinities in their way of thinking and working. One of the overall backgrounds was system theory and cybernetics. Max Bense became aware of Norbert Wiener through his book Cybernetics [1948]. In 1955 Bense invited Wiener for presentations in Stuttgart and Ulm. Bense had picked up the ideas of cybernetics, in wich he saw structural mathematical thinking combined with processes of controlling and steering and therefore technical procedures. He interpreted cybernetics as meta-technologies of machines. In his essay "Kybernetik oder die Metatechnik einer Maschine" [1951] he mentioned that the idea of representing mathematical thinking in a technical way originated in the works of Pascal and Leibniz, and that the new cybernetic extensions of technology led to a penetration of the microstructures of the world. Therefore, literature, art, music, design and architecture would also have been influenced 
and changed by cybernetics. By means of cybernetics, technologies were changed for him to meta- technologies. Later the approaches of cybernetics were combined with information theory based on Shannon and Weaver, because cybernetics requires information as its foundation. Bense's developments of information aesthetics and semiotics have their roots there. In this field he worked in collaboration with the French mathematician and social scientist Abraham A. Moles, who had a similar background in mathematical and structural thinking. They continued to work together even after the closing of HfG Ulm.

Abraham A. Moles, who studied physics and philosophy, taught cybernetics, information theory and semiotics in Ulm from 1961 to 1966 . He said in an interview:

The Ulm School of Design has given me the opportunity to advance an important step in the application of communication and information theory to the problems of perception as a necessary condition for a wilful shaping of the environment - for design ... [Krampen and Hörmann 2003: 91].

In his paper "Produkte - ihre funktionelle und strukturelle Komplexität" (Products: their functional and structural complexity) [1962] Moles explained his approach as based in structuring the world:

To catch the world, we have to capture it. To capture it, we have first to structure it. There are no structures it selves, but only perceived structures. The science as essential form of understanding of the world provides us at the same time measures and forms for this structuring.

This quote shows the common theoretical background of HfG Ulm in defining and representing the structures, as it was also explained by Max Bense in his theory, especially when he applied the information theory in aesthetics and therefore as a foundation for designing. In his book Aesthetica he wrote: "It is easy to see, that mathematical structures are general and abstract, so that they are usable to the reproduction of physical as well as aesthetic structures" [Bense 1982, p.173]. Therefore mathematics as the general science of structures, as it was developed especially by the Bourbakists, gives the overall relationship of mathematics and philosophy at Ulm School of Design [Leopold 2012].

After Bill's resignation (and, in solidarity with him, Bense's resignation as well) from HfG Ulm the curriculum was pushed in direction of "rendering the design process scientific" [Krampen and Hörmann 2003: 85]. The difference between the teachers, for example Bill and Maldonado, had been the role of art for design. The aesthetic factor was treated as just one factor among others, but the methodology for designing based on structures was extended. Regarding the situation at the time, Maldonado said:

It was the feverish insatiable curiosity directed especially toward some disciplines which were at the time in an upward phase: cybernetics, theory of information, systems theory, semiotics, ergonomics. Disciplines like philosophical theory of science and mathematical logic. The main spring of our curiosity, of our studies, and our theoretical efforts was our desire to give a solid methodological foundation to the working of design [Krampen and Hörmann 2003: 85].

In their paper "Wissenschaft und Gestaltung" [1964] Maldonado and Gui Bonsiepe listed the following mathematical disciplines as operable for the product designer in his design practice: 
1. Combinatorics (for modular construction systems and problems of measure coordination);

2. Group theory (as symmetry theory for construction of patterns and grids);

3. Theory of curves (for the mathematical treatment of transitions and transformations);

4. Polyhedral geometry (for the construction of regular, half regular and irregular solids);

5. Topology.

All these mathematical disciplines had already been taught in the foundation course, but were also used later in the design tasks. In this essay they especially emphasised the role of topology for the future. Moles had introduced the notions of "structural complexity" and "functional complexity". The categories had been used to analyse products according their elements and functions. Maldonado and Bonsiepe suggested adding the category of "topological complexity" in order to refine the analyses by looking for the connections between the elements. They claimed that construction diagrams could be useful in this context, in a way that was similar to how block diagrams were used for programming. At the time this idea was taken no further. The use of topology in a diagrammatic way - as Ben van Berkel uses it in his work, for example, in the Moebius House (1993-98) - may be a late proof of applying these ideas for designing.

\section{Conclusion}

The analysis of the foundation courses at Ulm School of Design shows different phases in how such courses were structured. Whereas Albers used an active geometric approach, Maldonado started with mathematical scientific knowledge implemented as a methodology for designing. As diverse as these approaches were, the general common background of HfG Ulm was structural thinking based on mathematics. The methodological experiments sometimes split away from application, and in some cases were carried out for their own sake, but they nevertheless had an impact on design methodology. Marcela Quijano, working in the HfG archive, remarks, "The Ulm School of Design made an essential contribution to the consolidation of a methodology which has had a lasting effect on design education worldwide" [Rinker, Quijano and Reinhardt 2003: 59]. Especially for digital design methods, the experiments became essential and in many cases were ahead of their time. The first computer experiments in art and design were influenced by Max Bense, Abraham A. Moles, and others. These experiments often shifted between precise and imprecise, order and chaos, rule and random, in practical applications of the information aesthetics. The methods, experiments, and ideas developed at Ulm School of Design have proved to be fruitful connecting points for today's digital rule-based and parametric design approaches.

\section{Acknowledgements}

The figures are reproduced by courteous permission of Martin Krampen, Ulm; HfG-Archiv, Ulmer Museum, Ulm; VG Bild-Kunst, Bonn; Hermann Edel, Darmstadt; Gui Bonsiepe, La Plata. The author is grateful for these kind permissions.

\section{References}

Baravalle, Hermann von. 1963. Geometrie als Sprache der Formen, 2nd edition. Stuttgart. (1st ed. 1957.)

Bense, Max. 1982. Aesthetica, 2nd edition. Baden-Baden. (1st ed. 1965.) 
Hamburg.

1949. Konturen einer Geistesgeschichte der Mathematik II. Die Mathematik in der Kunst.

. 1951. Kybernetik oder die Metatechnik einer Maschine. In: Merkur 5.

1998. Technische Existenz (1949). Pp. 49-158 in Max Bense: Ausgewählte Schriften, vol.

3. Stuttgart.

Bill, Max. 1949. Die mathematische Denkweise in der Kunst unserer Zeit. Werk 36, 3: 86-91.

Buchsteiner, Thomas and Otto Letze. 2005. Max Bill, Maler, Bildhauer, Architekt, Designer.

Ostfildern-Ruit.

EDEL, Hermann. 2012. Strukturelles Denken an der Hochschule für Gestaltung Ulm. Pp. 55-71 in

Strukturelle Architektur. Zur Aktualität eines Denkens zwischen Technik und Ästhetik,

Joaquín Medina Warmburg and Cornelie Leopold, eds. Bielefeld.

FroshaUG, Anthony. 1959. Visuelle Methodik. ulm 4.

hfg ulm. 2003. form+zweck 20. Berlin.

HfG-Archiv/Ulmer Museum, ed.. 2007. hfg ulm. Ulm School of Design 1953-1968. Ulm.

HfG-Archiv Ulm. http://www.hfg-archiv.ulm.de/english/the_hfg_ulm. Accessed 06 March 2013.

HufF, William S. 2000. Ordering Disorder after K. L. Wolf. Forma 15: 41-47.

Krampen, Martin and Günther Hörmann. 2003. Die Hochschule für Gestaltung Ulm / The

School of Design. Anfänge eines Projektes der radikalen Moderne / Beginnings of a Project of Radical Modernism. Berlin.

KRAMPEN, Martin. 2009. Observation and Formulation. Foundation course with exercises, based on a script by Josef Albers. DVD. Ostfildern-Ruit.

LeOPOLD, Cornelie. 2012. Strukturelles Denken als Methode. Pp. 9-29 in Strukturelle Architektur. Zur Aktualität eines Denkens zwischen Technik und Ästhetik, Joaquín Medina Warmburg and Cornelie Leopold, eds. Bielefeld.

Lindinger, Herbert, ed. 1987. Hochschule für Gestaltung Ulm ... Die Moral der Gegenstände. Berlin: Ernst \& Sohn.

Maldonado, Tomás and Gui BonsiePE. 1964. Wissenschaft und Gestaltung. ulm 10/11: 10-29. Available at http://ulmertexte.kisd.de/fileadmin/pdf/WissUndGest_CB_prt.pdf. Accessed 06 March 2013.

March, Lionel and Philip Steadman. 1974. The Geometry of Environment. Cambridge, MA, pp. $24 \mathrm{ff}$.

MOLES, Abraham A. 1962. Produkte - ihre funktionelle und strukturelle Komplexität. ulm 6. Available at: http://ulmertexte.kisd.de/fileadmin/pdf/Prod_Komplexitaet_BE_scr.pdf. Accessed 29 March 2013.

RinKeR, Dagmar, Marcela QUIJANO and Brigitte REINHARDT. 2003. ulmer modelle - modelle nach ulm. Hochschule für Gestaltung Ulm 1953-1968. Ulmer Museum/HfG-Archiv Publications. Stuttgart: Hatje Cantz.

Wiener, Norbert. 1948. Cybernetics: Or Control and Communication in the Animal and the Machine. Paris: Hermann \& Cie; Cambridge, MA: MIT Press.

Wolf, K. L. and R. WolfF, R. 1956. Symmetrie. Münster/Köln: Böhlau-Verlag.

\section{About the author}

Cornelie Leopold is an assistant professor and head of the Department of Descriptive Geometry and Perspective at the Faculty of Architecture, University of Kaiserslautern, Germany. She studied mathematics, philosophy and German at the University of Stuttgart. She has published several books and articles on the relationships between geometry and architecture, and has been a member of International Steering/Program Committees of numerous international conferences. She is VicePresident of the German Society for Geometry and Graphics (Deutsche Gesellschaft für Geometrie und Grafik - DGfGG), member of the Board Committee of the International Society for Geometry and Graphics (ISGG) as Director for Europe/Near East/Africa, and member of the editorial board of the Journal for Geometry and Graphics. She has been a guest lecturer at universities in Cracow, Istanbul and Milan. She coordinates the Erasmus Intensive Programme "Structural Architectures. Geometry, Code and Design". Her research interests are geometry and design, development of spatial visualisation skills, structural thinking in architecture, aesthetics and mathematics. More information is available at: www.architektur.uni-kl.de/geometrie. 